PURBAWIDYA: Jurnal Penelitian dan Pengembangan Arkeologi p-ISSN: 2252-3758, e-ISSN: 2528-3618 Terakreditasi Kementerian Ristekdikti No. 21E/KPT/2018 Vol. 8 (2), November 2019, pp 97 - 111 DOI: https://doi.org/10.24164/pw.v8i2.305

\title{
GUNUNG SEBAGAI LOKASI SITUS-SITUS KEAGAMAAN DAN SKRIPTORIA MASA SUNDA KUNO
}

\section{Mountain as Religious Site and Scriptoria during Ancient Sunda Period}

\author{
Dani Sunjana \\ Divisi Penelitian dan Kajian Gumati Foundation \\ Jalan Raya Garut-Tasik Km 70, Desa Tenjowaringin, Kecamatan Salawu, \\ Kabupaten Tasikmalaya \\ E-mail: danisunjana@gmail.com
}

Naskah diterima:13 Juni 2019 - Revisi terakhir: 31 Oktober 2019

Disetujui terbit: 28 November 2019 - Tersedia secara online: 30 November 2019

\begin{abstract}
This research aimed to reconstruct the concept, value, and implication of mount as sacred landscape in Ancient Sunda period. The research used bibliographical method which combine the information interpretation from secondary philology and epigraphical sources with previously done archaeological researches. The result showed that mount and mountain in general used as a sacred and holy landscape in Ancient Sunda period. This conception then represented by the existence of religious sites and scriptoria at the mount as a symbol to decrease the spiritual and intelectual distance with the deities and Supreme Being. Several mounts has been mentioned on written sources and need further archaeological research as a crosscheck confirmation in the future.
\end{abstract}

Keywords: Ancient Sunda, mount, religious sites, scriptoria

\begin{abstract}
Abstrak
Penelitian ini bertujuan untuk merekonstruksi kedudukan gunung dan pegunungan sebagai lanskap suci dan implikasinya pada masa Sunda Kuno. Jenis penelitian yang digunakan merupakan penelitian pustaka yang memadukan interpretasi naskah-naskah dan prasasti kuno dari sumber sekunder dengan hasil-hasil penelitian arkeologi yang telah dilakukan. Berdasarkan hasil penelitian tampak bahwa gunung telah digunakan sebagai simbol yang sakral dan suci pada masa Sunda Kuno. Pandangan ini kemudian diwujudkan dengan cara membangun situs-situs keagamaan serta skriptoria sebagai upaya untuk memperdekat jarak rohani dan kesempurnaan pengetahuan dengan dewata dan kebenaran tertinggi. Gunung-gunung suci dan sakral masa Sunda Kuno beberapa di antaranya telah disebutkan dalam sumber-sumber tertulis dan perlu dikonfirmasi melalui penelitian arkeologis pada masa mendatang.
\end{abstract}

Kata kunci: Sunda Kuno, gunung, bangunan suci keagamaan, skriptoria

\section{PENDAHULUAN}

Gunung merupakan lanskap alam yang telah dikenal memiliki nilai sakral dalam berbagai peradaban dan religi dunia (Laneri, 2015). Sejumlah gunung, seperti Himalaya (Nepal), Sinai (Mesir), dan 
Fuji (Jepang), merupakan contoh populer mengenai hal ini. Menurut Bernbaum (2006), kesakralan gunung dalam berbagai budaya dapat termanifestasi dalam tiga cara. Pertama, puncak gunung lazim dimaknai sebagai tempat paling suci dan berkaitan dengan mitos, kepercayaan, dan sejarah agama tertentu sehingga kemudian dijadikan sebagai lokasi ziarah (pilgrimage), meditasi, atau ritus kurban tertentu. Kedua, gunung sering diasosiasikan dengan tokoh suci/ mistis yang termanifestasi dalam bentuk bangunan atau objek sakral, seperti kuil atau objek alami lain, misalnya batu dan air terjun. Ketiga, gunung dianggap sebagai lanskap yang mampu membuka kesadaran dan kebijaksanaan tertinggi manusia. Oleh karena itulah, gunung kerap dijadikan tempat untuk bermeditasi dan merenung (Bernbaum, 2006). Hal tersebut berlaku universal, tidak terkecuali di Indonesia.

Gunung telah dianggap sebagai lanskap yang sakral dan disucikan sejak masa prasejarah di Indonesia. Fenomena ini terutama tampak pada masyarakat dengan pola budaya megalitik yang menganggap gunung sebagai tempat tinggal arwah leluhur (Soejono, 2008). Akibatnya, gunung kemudian menjadi orientasi suci yang dijadikan kiblat dalam ritual-ritual keagamaan serta lanskap yang lazim digunakan untuk mendirikan bangunanbangunan suci. Beberapa kawasan gunung di Indonesia yang dikenal sebagai gunung suci pada masa prasejarah misalnya adalah Gunung Dempo di Sumatra Selatan yang menjadi orientasi dari situs-situs megalitik di Pasemah (Guillaud, 2006), Gunung Sago di Sumatra Barat (Prasetyo \& Yuniawati, 2004), dan Gunung Slamet di Purwokerto, Jawa Tengah (Sulistyarto, 2003). Pada perkembangannya tidak hanya gunung yang dijadikan tempat suci, tetapi pula bukit-bukit atau lanskap buatan yang ditinggikan dan dipandang memiliki kesejajaran makna sebagai tempat yang tinggi, tempat persemayaman arwah leluhur (Laksmi \& Wahyudi, 2018).

Penggunaan gunung sebagai simbol sakral pada masa prasejarah semakin berkembang pada masa Hindu Buddha di Indonesia. Pada masa ini, gunung sebagai lanskap suci dikaitkan dengan mitologi Hindu India, Mahameru. Mahameru merupakan gunung kosmis, pusat dari alam semesta, digambarkan terletak pada pulau yang berada di tengah samudera, dan dikelilingi enam benua konsentris. Pada puncakgunung Mahameru inilah para dewa tinggal dalam arah dan tempat tertentu yang disebut sebagai loka. Brahma tinggal di bagian yang disebut Brahmâloka, Indra di Indraloka (swarga), Wisnu di Vaikuntha, Siwa di Kailasa, Kuwera di Mahodaya, dan lain-lain (Williams, 2003). Mitologi mengenai Mahameru kemudian diadaptasi ke dalam kebudayaan Jawa. Pada naskah Tantu Panggelaran (XVI M), Gunung Mahameru dikisahkan dipindahkan oleh para dewa dari tempat asalnya di Jambudwipa (India) ke Pulau Jawa agar Jawa tidak terombang-ambing dan tenang dari ancaman gelombang samudera. Selama pemindahan Mahameru, terdapat bagian-bagian yang jatuh dan menjelma menjadi gunung-gunung di sepanjang Pulau Jawa. Adapun puncaknya diletakkan di wilayah Jawa Timur dan menjadi Gunung Pawitra atau Penanggungan, gunung yang diidentifikasi sebagai pusat dan orientasi religius, yaitu pada masa Mataram Kuno, Kadiri, Singasari, hingga Majapahit (Munandar, 2016).

Gunung kosmik Mahameru ini kemudian dijadikan landasan dalam 
kosmologi kerajaan-kerajaan di Jawa selama periode Hindu-Buddha. Gunung dijadikan orientasi utama dalam konfigurasi situs-situs keagamaan. Gunung Merapi di Yogyakarta pada Mataram Kuno agaknya dianggap sebagai Mahameru mengingat padatnya temuan bangunan suci berupa candi di kawasan kaki gunung ini meskipun belum didukung dengan data tertulis yang memadai (Degroot, 2009). Setelah perpindahan pusat kerajaan Mataram Kuno ke wilayah Jawa Timur, yaitu Pawitra, yang diidentifikasi sebagai Gunung Penanggungan dijadikan sebagai pusat orientasi suci kerajaan hingga masa Majapahit. Pada masa ini posisi Pawitra sebagai gunung kosmik dan sakral semakin jelas dengan keberadaan ratusan bangunan keagamaan yang didirikan sepanjang kaki, badan, hingga puncaknya (Munandar, 2016). Selain Penanggungan, gununggunung lain di Jawa Timur, seperti Semeru dan Arjuna, juga pernah menjadi situs keagamaan yang penting pada masa ini.

Pada masa Majapahit gunung
juga berkembang menjadi pusat
intelektual sebagai kompleks mandalal kedewaguruan. Mandala/kedewaguruan merupakan kompleks asrama, tempat pendidikan agama, yang dipimpin oleh seorang dewaguru dari kaum rsi (pertapa). Bersama dewaguru, pada kompleks mandala tinggal pula para pendeta dan pembantu serta murid-murid yang menuntut ilmu keagamaan (Santiko, 2005). Pusat-pusat intelektual dan pendidikan agama ini banyak menghasilkan berbagai naskah-naskah sastra dan keagamaan serta prasasti-prasasti dengan corak khusus sehingga sering disebut sebagai situs skriptorium (jamak: skriptoria). Salah satu skriptorium yang telah teridentifikasi misalnya adalah skriptorium Damalung, berada di kawasan pegunungan MerapiMerbabu. Satu prasasti bercorak khusus dan empat ratus naskah lontar ditemukan darikawasan ini(Susanti, 2018). Damalung sebagai kompleks mandala juga disebut dalam naskah Perjalanan Bujangga Manik pada waktu ia memperdalam ilmu agama di tanah Jawa (Noorduyn, 1982). Selain Perjalanan Bujangga Manik, beberapa naskah Jawa Kuno juga menyebutkan adanya mandala yang dibangun pada kawasan gunung, seperti naskah Tantu Panggelaran yang menyebut dua mandala istimewa dari sistem chaturbhasma, yaitu Mandala Sukayajna di utara/timur gunung Kailasa dan Mandala Kukub di arah selatan Mahameru (Santiko, 2005).

Fenomena gunung sebagai orientasi dan pusat aktivitas religius sesungguhnya juga terjadi di Jawa bagian Barat yang merupakan wilayah kerajaan Galuh dan Sunda Kuno pada masa HinduBuddha, tetapi hal ini masih sangat sedikit diperbincangkan. Pada masa inisejajar dengan kasus di Jawa Tengah dan Timur-gunung menjadi orientasi dan pusat keagamaan yang penting. Artikel ini membahas gunung sebagai lokasi dari situs-situs keagamaan dan skriptoria di Jawa Barat berdasarkan keterangan sumber-sumber tertulis serta data arkeologis yang memiliki kesejajaran dengan fenomena serupa pada gununggunung di wilayah bagian Jawa Tengah dan Timur. Jenis data dalam tulisan ini merupakan data sekunder sesuai dengan jenis penelitiannya sebagai penelitian kepustakaan . Data sekunder adalah jenis data yang berasal dari hasil penelitian para ahli berbagai disiplin ilmu, seperti arkeologi, geografi, dan filologi yang diterbitkan dalam bentuk buku, jurnal, ataupun laman internet (Moleong, 2007). 
Data-data yang terkumpul selanjutnya dianalisis dan disajikan secara deskriptif guna memberikan gambaran secara umum mengenai peranan religius gunung sebagai lokasi-lokasi situs keagamaan dan skriptoria pada masa Sunda Kuno yang perlu dibarengi dengan kajian lapangan (field research) pada masa mendatang.

\section{HASIL DAN PEMBAHASAN}

\section{Gunung-Gunung Suci di Jawa Barat dan Banten dalam Sumber-Sumber Tertulis}

Sejumlah gunung di Jawa Barat dan Banten dapat diidentifikasi sebagai lokasi tempat suci dan skriptorium pada masa lalu berdasarkan data toponim dalam sumber-sumber tertulis kuno. Penyebutan gunung-gunung sebagai toponim tempat suci pada beberapa naskah ada yang dapat diidentifikasi dan dikonfirmasi dengan temuan data arkeologis, ada pula yang masih perlu dilacak. Beberapa gunung yang dapat diidentifikasi sebagai gunung suci di Tatar Sunda (Jawa Barat dan Banten) berdasarkan sumber-sumber tertulis adalah Gunung Raksa, Gunung Gede, Gunung Galunggung, Gunung Cikuray, Kompleks Gunung Malabar, Gunung Salak, serta Gunung Ciremai.

\section{- Gunung Raksa}

Gunung Raksa merupakan gunung yang terletak di Pulau Panaitan, Ujung Kulon, Banten. Toponim gunung ini sebagai gunung suci disebut dalam naskah Perjalanan Bujangga Manik, seperti dikutip Aditia Gunawan (2011: 1) sebagai berikut.

Itu ta na Gunung Raksa itulah Gunung Raksa

\section{Gunung Sri Mahapawitra \\ Gunung Sri Mahapawitra \\ tanggerana Panahitan \\ poros di Panahitan}

Dalam naskah tersebut, Gunung Raksa disebut sebagai Mahapawitra. Menarik perhatian bahwa Mahapawitra juga disebut dalam naskah-naskah Sunda Kuno lain, yaitu Sanghyang Hayu (Kropak 634 dan 637), Siksaguru, dan Sanghyang Sasana Mahaguru (Kropak 621) pada bagian kolofon yang menyebutkan gunung ini sebagai lokasi penyusunan karyakarya tersebut (Gunawan, 2011). Dengan demikian, Gunung Raksa adalah situs skriptorium di Jawa bagian Barat pada masa tersebut. Fakta ini didukung pula oleh dua naskah Sunda kuno lain, yaitu Carita Raden Jayakeling (Kropak 407) dan Tutur Bwana (Kropak 620) yang mengonfirmasi Panaitan sebagai tempat yang disucikan. Dalam naskah Carita Raden Jayakeling disebutkan bahwa di Panaitan terdapat kabuyutan, yaitu Susuhunan Hujungkulan. Kabuyutan sendiri merupakan bangunan suci yang lazim dikenal pada masa Sunda Kuno (Munandar, 2017). Adapun dalam Tutur Bwana, Panaitan disebutkan sebagai salah satu dari tiga tempat penting di Tatar Sunda dalam kosmologi dunia selain Hujungkulan dan Gunung Langlayang (Gunawan, 2011). Hal yang patut diperhatikan pula adalah keterangan dari nakah Jawa Kuno, Tantu Panggelaran, yang menyebutkan bahwa pada mulanya Mahameru ditempatkan oleh para dewa di Jawa bagian Barat dan dinamai Gunung Kelasa, sebelum kemudian dipindahkan ke Jawa Timur karena rupa-rupanya kondisi tanah Jawa disebutkan menjadi berat sebelah. Apakah Gunung Raksa kiranya dapat diidentifikasi sebagai Mahameru 
Kelasa tersebut karena pada masa lalu agaknya Gunung Raksa sejajar sebagai pawitra, seperti Gunung Penanggungan yang merupakan mahameru Jawa Kuno'

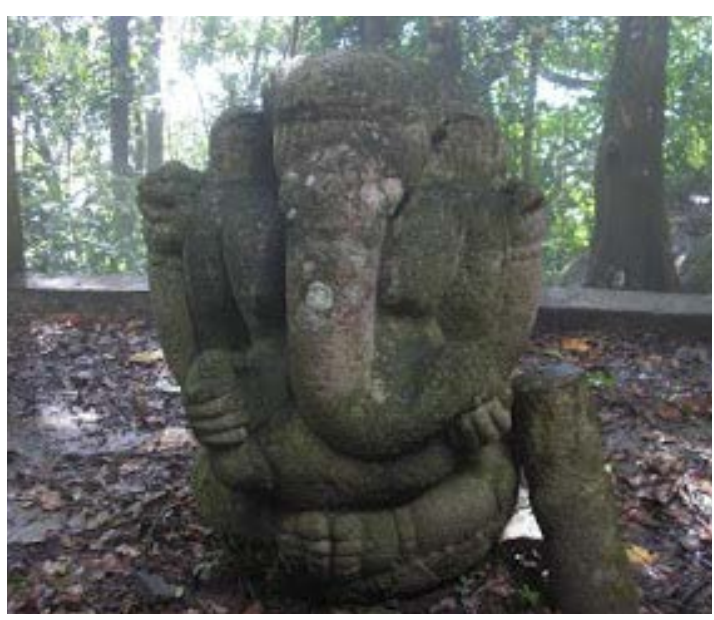

Gambar 1 Arca Ganesha di Gunung Raksa, Panaitan, Banten (Sumber: wikimedia.org, 2018)

Eksistensi Gunung Raksa sebagai tempat suci juga terkonfirmasi melalui data arkeologis yang ditemukan tepat di kawasan gunung tersebut, yaitu berupa arca Siwa dan Ganesha. Arca Ganesha tersebut masih in situ pada Situs Gunung Raksa, sedangkan arca Siwa sebelumnya pernah dicuri, tetapi telah berhasil ditemukan kembali dan sekarang berada di Museum Sri Baduga (Tim Penulis Sejarah Nasional Indonesia, 2009). Keberadaan kedua arca ini menjadi menarik, terutama keberadaan arca Ganesha. Bhatara Gana atau Ganesha disebut sebagai istadewata pengarang teks Sanghyang Sasana Mahaguru. Dalam naskah tersebut, Ganesha disebut sebagai pelindung dan pencipta lontar dan gebang yang dipakai oleh penulisnya (Gunawan, 2011).

1 Munandar (2016) mengidentifikasi Gunung Kelasa sebagai Gunung Salak, Bogor. Lihat pula penjelasan mengenai Gunung Salak dalam tulisan ini.

\section{- Gunung Gede}

Gunung Gede terletak di Kabupaten Bogor. Berdasarkan naskah Perjalanan Bujangga Manik, Gunung Gede dan Pangrango ini disebut sebagai Bukit Ageung. Noorduyn mengidentifikasi Bukit Ageung sebagai Gunung Gede, barangkali karena kesejajaran kata ageung dengan gede yang berarti 'besar'. Hal ini dapat kita simak dalam petikan berikut.

Sadatang ka Bukit Ageung,

Setibanya di Bukit Ageung

eta hulu Cihaliwung,

(yang merupakan) hulu Sungai

Ciliwung

Kabuyutan ti Pakuan,

Kabuyutan dari Pakuan

Sanghiang Talaga Warna.

Sanghiang Talaga Warna.

(Noorduyn, 1982: 419)

Informasi naskah Perjalanan Bujangga Manik di atas menyebutkan bahwa Gunung Gede merupakan gunung sakral karena merupakan kabuyutan dari Kerajaan Pakwan Pajajaran (abad ke-15-16 M) yang berlokasi di Bogor sekarang. Apabila identifikasi tersebut benar, di Gunung Gede pada masa Sunda Kuno pasti terdapat bangunan suci yang cukup besar karena berstatus sebagai kabuyutan kerajaan. Menarik untuk diperhatikan pula adalah frasa Sanghiang Talaga Warna yang sesungguhnya dapat merujuk kepada bangunan suci yang terletak di Telaga Warna. Seperti diketahui bahwa kata sanghyang berasal dari kata sang + hyang dan lazim digunakan sebagai kata sandang dari hal-hal yang bersifat sakral atau suci. Apakah yang dimaksud Telaga Warna menurut Bujangga Manik dapat dihubungkan dengan Telaga Biru, telaga 
di tengah hutan yang dapat diakses ketika melakukan pendakian lewat jalur Cibodas. Hal ini memerlukan penelitian lebih lanjut di masa yang akan datang.

\section{- Gunung Galunggung}

Gunung Galunggung merupakan gunung yang berlokasi di Kabupaten Tasikmalaya. Berdasarkan naskah Amanat Galunggung (Danasasmita, 1981), gunung ini merupakan situs kabuyutan kerajaan yang sangat penting dan berharga pada masa Sunda Kuno. Mengingat pentingnya kabuyutan ini, pada bagian awal naskah disebutkan bahwa anak dan keturunan Rakeyan Darmasiksa serta masyarakat umum wajib menjaga kabuyutan Galunggung agar tidak dikuasai oleh musuh atau orang asing.

Jika dilihat dari sisi arkeologis, pada tahun 1887 K.F. Holle, seorang peminat kajian Sunda, menemukan prasasti di Kampung Geger Hanjuang, Desa Linggamulya, Kecamatan Leuwisari, yang merupakan salah satudesa dilereng Gunung Galunggung. Prasasti tersebut selanjutnya disebut prasasti Geger Hanjuang dan berisi informasi mengenai pembangunan parit oleh Bhatari Hyang. Agus Aris Munandar (2017) berpendapat bahwa Bhatari Hyang kemungkinan besar adalah seorang mahabhiksuni/rsi perempuan yang melakukan praktik pertapa (wanaprastha) hingga meninggal. Dengan demikian, Bhatari Hyang merupakan seorang rsi (pertapa) yang tinggal dan memiliki peran besar di kabuyutan Galunggung pada masa tersebut, selain sebagai tempat suci, gunung ini kemungkinan besar juga merupakan skriptorium apabila merujuk pada keberadaan naskah Amanat Galunggung, yang harusnya disusun di Galunggung. Akan tetapi, tentu hal ini harus diteliti lebih lanjut, mengingat naskah tersebut ditemukan di Situs Ciburuy, Garut.

\section{- Gunung Cikuray}

Gunung Cikuray terletak di Kabupaten Garut. Gunung ini memiliki nama kuno Srimanganti atau Srimanganten berdasarkan nama salah satu tempat di lereng barat gunung tersebut, tetapi dalam naskah Bujangga Manik sudah disebut sebagai Cikuray. Peran penting Gunung Cikuray sebagai tempat suci antara lain dibuktikan dengan keberadaan Situs Ciburuy yang merupakan kabuyutan serta skriptorium pada masa lampau. Situs Ciburuy secara administratif berada di Kampung Ciburuy, Desa Pamalayan, Kecamatan Bayongbong, Kabupaten Garut.

Situs Ciburuy hingga saat ini masih menerapkan tradisi lama, dalam kompleks situs terdapat bangunan-bangunan tradisional dari bahan kayu dan bambu. Bangunan-bangunan tersebut antara lain adalah patemon (balai pertemuan dan musyawarah), leuit (lumbung padi), saunglisung (bangunan tempat menumbuk padi), padaleman (bangunan beruang tiga, tempat belajar dan mengajar yang disesuaikan dengan tingkat pengetahuan), serta panyarangan (tempat penyimpanan naskah dan wadah naskah sementara). Beberapa data arkeologi berupa artefak lepas disimpan di dalam bangunan patemon dalam peti yang berisi beberapa lembaran naskah berbahan saeh dan beraksara pegon serta benda-benda pusaka berupa sebatang rotan berukuran empat puluh sentimeter yang dibungkus kain warna merah-putih, dua bilah golok panjang, beberapa bilah keris, cambuk, rantai logam keemasan, alat kecantikan, bokor tembaga, dan gamelan. Data yang sangat penting 
berupa tiga peti kayu yang masing-masing berisi kropak dan bundelan naskah yang berbahan lontar dan nipah beserta benda pusaka yang berupa kujang, trisula, genta, dan artefak logam lainnya yang disimpan dalam bangunan padaleman (Darsa, 2010). Selain itu, dalam kompleks Situs Ciburuy juga terdapat beberapa susunan batu megalit yang masih dikeramatkan.

\section{- Kompleks Gunung Malabar}

Gunung Malabar merupakan gunung api purba yang terletak di Pangalengan, Kabupaten Bandung, Jawa Barat. Gunung ini memiliki empat puncak tertinggi, yaitu Gunung Wayang, Gunung Haruman, Gunung Batu, serta Gunung Puntang. Gunung Malabar, Gunung Wayang, dan Gunung Puntang disebutkan dalam naskah Perjalanan Bujangga Manik. Menarik untuk diperhatikan bahwa setelah melakukan pendakian Gunung Wayang, Bujangga Manik tiba di mandala yang disebut sebagai Mandala Beutung. Begitu pula setelah ia mendaki Gunung Patuha, ia tiba di Mandala Ranca Gonda dan tinggal sebagai pertapa selama satu tahun, sebelum kemudian ia pergi ke Gunung Ratu, di kaki Gunung Patuha, dan mendirikan bangunan suci dan tempat tinggal (Setiawan, 2019). Keterangan dari naskah ini memberikan informasi bahwa pada masa lalu, kompleks Gunung Malabar adalah gunung yang keramat dan disucikan.

Indikasi adanya bangunan suci di Gunung Wayang terdapat dalam laporan kepurbakalaan N.J. Krom, Rapporten Oudeheidkundige Dienst, pada tahun 1914. Dalam laporannya, N.J. Krom menjelaskan bahwa di puncak Gunung Wayang ditemukan empat puluh arca dan kuburan kuno yang di dalamnya ditemukan pula pecahan tembikar, kapak batu, dan tulang- belulang. Arca bermahkota dengan bentuk mirip meriam dan guci juga ditemukan di dekat mata air Citarum di Situ Cisanti. Sumber lain yang juga menyebutkan adanya data arkeologis di Gunung Wayang adalah catatan Marie Gray, seorang dokter asal Selandia Baru pada tahun 1960-an yang dibukukan dengan judul Tāmu: a New Zealand family in Java (1988). Marie Gray, pada salah satu bagian buku tersebut, menceritakan pengalamannya mendaki Gunung Wayang dan menemukan enam arca tipe Polinesia. Pada pendakian tersebut, Gray ditemani juru kunci yang memberitahukannya nama arca-arca tersebut sehingga ia dapat menggambar sketsa situs lengkap bersama nama-nama arcanya (Widjajadi, 2018).

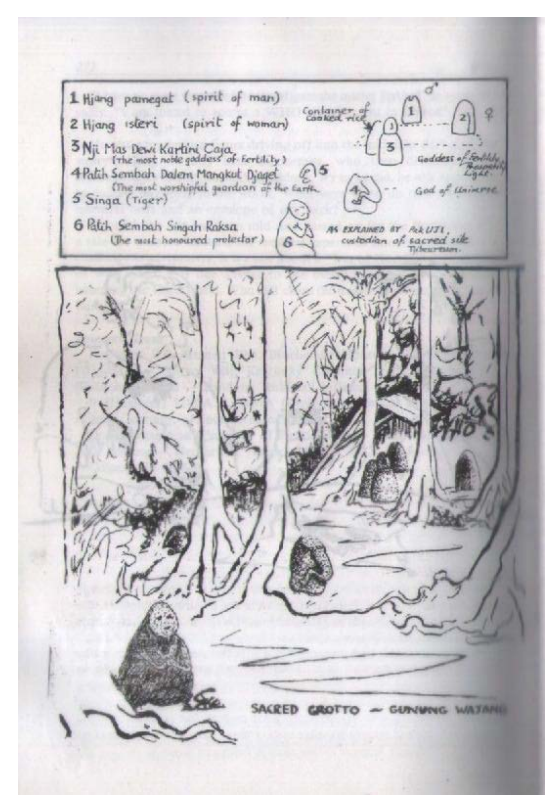

Gambar 2 Rekonstruksi Arca-Arca Tipe Polinesia di Gunung Wayang dalam Buku Tâmu: a New Zealand Family in Java (1988) oleh Marie Gray (Sumber: Widjajadi, 2018)

Adapun Mandala Ranca Gonda di Patuha barangkali dapat dilacak di sekitar Patenggang atau kawah-kawah mati yang membentuk ranca di sekitar Kawah Putih. 
Sanghyang Carengcang, yang merupakan pertapaan yang dibangun, diperindah, dan digunakan oleh Bujangga Manik selama sepuluh tahun juga dikatakan berada di kaki (landeuh) Gunung Patuha, di hulu sungai Cisokan. Informasi-informasi tersebut memerlukan penelusuran arkeologi lebih lanjut di masa yang akan datang.

\section{- Gunung Salak}

Gunung Salak berada di Kabupaten Bogor. Gunung ini tidak disebutkan secara jelas pada naskah-naskah Sunda Kuno, tetapi dalam kisah-kisah pantun Bogor dinamakan Giri Dwi Munda Mandala 'gunung dengan dua puncak' (Munandar, 2016). Pendapat ini menarik jika dibandingkan dengan keterangan Bujangga Manik yang menyebutnya dengan Bukit Ageung, Gunung Gede menurut tafsir Noorduyn, sebagai kabuyutan Pakwan.

Kedua pendapat ini menarik dan membutuhkan diskusi yang lebih panjang karena akan berimplikasi pada adanya dua Mahameru di Pakwan Pajajaran. Terlepas dari hal tersebut, Gunung Salak sudah lama dikenal dengan kekayaan tinggalan arkeologi berupa situs-situs megalit. Di kaki Gunung Salak terdapat sejumlah situs, seperti kompleks situs megalitik Cibalay (Kecamatan Tenjolaya, Kabupaten Bogor) dan Calobak (Kecamatan Tamansari, Kabupaten Bogor).

\section{- Gunung Ciremai}

Ciremai merupakan gunung tertinggi di Jawa Barat yang berlokasi di Kabupaten Kuningan. Kata Ceremay disebutkan dalam naskah Bujangga Manik ketika ia pergi ke Conam dan Darma Kuningan. Bujangga Manik tidak menyebutkan adanya bangunan suci di Ciremai, tetapi situs-situs megalit yang sangat mungkin merupakan kabuyutan banyak tersebar di kaki gunung ini, seperti Situs Cimara, Cibunar, Sigenteng, Sangkanerang, Timbang, Linggabuana, Buyut Sukadana, Balongkagungan, Nusa, Cangkuang, Winduherang, Bagawat, Darmaloka, Hululinga, Panyusupan, dan Saliya (Yondri, 2018).

\section{Gunung sebagai Lokasi Situs-Situs Bangunan Suci dan Skriptoria di Tatar Sunda pada Masa Sunda Kuno}

Keterangan yang diberikan dalam sumber-sumber tertulis mengenai gunung dan situs-situs keagamaan di Tatar Sunda sangatlah terbatas dan fragmentaris. Naskah Bujangga Manik dan Sanghyang Sasana Maha Guru, misalnya, hanya menyebut beberapa nama gunung di Tatar Sunda sebagai lokasi bangunan suci secara sepintas-sepintas. Pada kenyataannya, situs-situs bangunan suci sangat banyak tersebar pada gunung-gunung lain yang bahkan tidak pernah disebut dalam prasasti ataupun naskah-naskah kuno lain. Beberapa di antaranya masih dikeramatkan dan dijadikan tempat pemujaan. Situssitus baru juga kemungkinan akan terus ditemukan pada masa yang akan datang.

Adanya bangunan-bangunan suci yang didirikan pada kawasan gunung/ pegunungan menunjukkan pentingnya lanskap ini dalam ideologi religius masyarakat Sunda pada masa silam. Dalam tradisi prasejarah, gunung dianggap sesuatu yang suci dan keramat serta diyakini sebagai tempat bersemayamnya roh-roh nenek moyang (Soejono, 2008). Adapun dalam kosmologi Hindu dikenal adanya pelapisan jagat menjadi tiga bagian (triloka) dan disimbolkan sebagai Gunung Mahameru beserta penghuninya. Bagian paling bawah disebut bhurloka, disimbolkan sebagai kaki Gunung 
Mahameru. Pada bagian ini hidup manusia pada umumnya serta berbagai jenis hewan. Dengan demikian, pada bagian ini mahluk yang hidup masih terikat oleh hasrat dan kebutuhan duniawi. Bagian selanjutnya disebut sebagai bhuwarloka, disimbolkan sebagai bagian lereng tengah gunung dan merupakan tempat hidup kaum pertapa, para $r s i$, dan orang-orang suci yang telah menindas hasrat duniawi. Bagian paling atas disebut swarloka dan disimbolkan sebagai puncak gunung yang merupakan tempat persemayaman para dewa (Munandar, 2017). Agama Buddha memiliki konsep kosmologi yang membagi dunia dalam tiga bagian juga, yaitu kamadhatu, rupadhatu, dan arupadhatu. Ketiga dhatu ini juga disimbolkan sebagai Mahameru, tetapi agakberbeda dengankonsep triloka Hindu. Kamadhatu merupakan dunia tempat hidup bermacam hewan dan manusia yang masih dipenuhi oleh segala hasrat dan hawa nafsu dan disimbolkan sebagai bagian kaki Mahameru. Rupadhatu yang disimbolkan sebagai bagian tengah lereng Mahameru merupakan tempat tinggal mahluk suci yang telah berhasil melepaskan hasrat dan nafsu, tetapi masih terperangkap dalam rupa (hidup). Arupadhatu adalah bagian paling atas dan disimbolkan dengan puncak Mahameru dan merupakan nirwana yang kosong (sunyata), terbebas dari wujud ataupun rasa. Pada tataran arupadhatu, seorang mahluk sudah bebas dari reinkarnasi dan bersatu dengan kesunyataan (Munandar, 2016).

Masyarakat Sunda Kuno pada masa lalu juga mengenal pembagian dunia dalam tiga tingkatan alam yang disebut sebagai bumi sakala, buana niskala, dan buana jatiniskala. Bumi sakala adalah alam nyata di dunia tempat kehidupan makhluk yang memiliki jasmani (raga) dan rohani (jiwa). Makhluk demikian adalah yang disebut manusia, hewan, tumbuhan, dan benda lain yang dapat dilihat, baik yang bergerak maupun yang tidak bergerak. Buana niskala adalah alam gaib sebagai tempat tinggal makhluk gaib yang wujudnya hanya tergambar dalam imajinasi manusia, seperti dewa-dewi, bidadara-bidadari, dan apsara-apsari. Jumlah dan ragam makhluk tersebut banyak dan dapat bergabung satu dengan lainnya serta berkedudukan lebih tinggi daripada manusia. Buana niskala yang disebut juga kahyangan terdiri atas surga dan neraka. Naskah Jatiraga (Kropak 422) menyebutkan Pwah Batari Sri, Pwah Lengkawati, Pwah Wirumananggay, dan Dayang Trusnawati sebagai penghuni buana niskala. Di samping itu, penghuni buana niskala lainnya di antaranya adalah sembilan dewi, seperti Dewi Tunyjung Herang, Dewi Sri Tunyjung Lenggang, Dewi Sari Banawati, dan 45 bidadari yang disebutkan namanya, antara lain Bidadari Tunyjung Maba, Bidadari Naga Nagini, Bidadari Endah Patala, dan Bidadari Sedajati. Buana jatiniskala adalah alam kemahagaiban sejati sebagai tempat tertinggi di jagat raya. Penghuninya adalah zat Maha Tunggal yang disebut Sang Hyang Manon, zat Maha Pencipta yang disebut Si Ijunajati Nistemen. Zat inilah yang tingkat kegaiban dan kekuasaannya paling tinggi. Dialah pencipta batas, tetapi tak terkena batas. Dengan demikian, tiap-tiap alam mempunyai penghuninya masing-masing yang wujud, sifat, tingkat, dan tugas/kewenangannya berbeda (Ekadjati, 2005).

Kosmologi Sunda ini sesungguhnya dapat disejajarkan dengan konsep 
kosmologi Hindu dan Buddha dengan menjadikan gunung sebagai analogi setiap tingkat dunia. Naskah Kosmologi Sunda (Kropak 420) menyebut bahwa Pwah Wiru Mananggay didampingi Danghyang Trusnawati tinggal di gunung bernama Gunung Jati untuk menjaga bangunan suci Bungawari di Pasekulan bukit Tri Jantra si Jatri Palasari. Dewi-dewi tersebut, jika merujuk pada konsep tribuana, berada pada posisi tengah/lereng gunung, sedangkan manusia biasa dan mahluk-mahluk lain berada di bawahnya. Sang Hyang Manon berada pada tingkatan tertinggi di puncak gunung karena dari posisi inilah secara analogis, pandangan dapat ditujukan ke segala arah (Sang Hyang Manon: Wujud Yang Maha Melihat). Dengan demikian, gunung sesungguhnya merupakan simbol perjalanan spiritual menuju Kebenaran Tertinggi dari masyarakat Sunda Kuno. Pembangunan situs-situs keagamaan di wilayah pegunungan dengan demikian bertujuan untuk memperdekat jarak secara simbolis kepada wujud-wujud gaib, seperti pwah dan hyang yang merupakan dewa dan dewi yang menjaga unsur-unsur alam, bhatara-bhatari yang merupakan arwah leluhur yang telah mangkat dan diperdewa, serta Si Ijunajati Nistemen sebagai wujud Kebenaran Tertinggi.

Mengenai bentuk suatu kabuyutan, naskah Bujangga Manik memberikan keterangan yang sangat berharga, terutama pada baris 1411-1417. Dalam petikan naskah tersebut dikatakan bahwa kabuyutan didirikan sebagai bangunan yang berundak-undak dengan cara menyusun batu-batu di sekelilingnya. Pada bagian bawah bangunan disusun batu-batu datar, sedangkan pada bagian atas terdapat batu tegak yang dilengkapi dengan batu putih dan taburan manik-manik permata yang berkilauan. Keterangan ini mengingatkan kita dengan bangunan punden berundak yang banyak ditemukan di Tatar Sunda. Lebih lanjut, menurut Munandar (2017: 156), kabuyutan ini biasa dihuni oleh rama dan rsi, serta merupakan kompleks permukiman kecil yang besarnya berada di bawah mandala dan setingkat dengan kewikuan. Di dalam kompleks kabuyutan juga terdapat bangunan pemujaan dewa yang disebut dewasasana. Mengenai dewasasana, patut dicermati keterangan Prasasti Kebantenan II dan III (Prasasti Sunda Sembawa) dan IV (Prasasti Gunung Samaya) yang dikeluarkan oleh Sri Baduga Sang Ratu Dewata (1482-1521 M) (Septiani, 2010). Dalam prasasti Kebantenan II dan III, Sri Baduga menetapkan wilayah Sunda Sembawa sebagai daerah perdikan yang harus dilindungi dan dipelihara bersama karena di sana terletak kabuyutan yang dihuni oleh para wiku serta terdapat dewasasana yang merupakan sanggar pemujaan raja (dewasasana sanggar kami ratu). Dalam Prasasti Kebantenan IV, raja juga dikatakan mengukuhkan tanah dewasasana di Gunung Samaya yang tidak boleh diganggu secara fisik atau dikenakan pajak (Septiani, 2010). Bentuk dewasasana belum diketahui secara pasti, tetapi dapat diperkirakan berupa fitur atau artefak megalit yang dilengkapi batu tegak berupa menhir atau arca-arca sederhana tipe Pajajaran yang merupakan simbol dari dewa-dewa tertentu secara khusus.

Sangat menarik bahwa pada masa yang sama di Majapahit juga berkembang institusi pendidikan agama yang disebut mandala/kedewaguruan. Menurut Hariani Santiko (2005: 116), mandala/ kedewaguruan adalah wanasrama yang berbentuk kompleks perumahan pertapa 
yang disusun sedemikian rupa sehingga tapowana atau pajaran (tempat tinggal dewaguru, pemimpin mandala) berada di tengah-tengah. Karena tempat tinggal pemimpin mandala berada di tengah dan para pertapa dengan strata sosial/ pengetahuan religius yang lebih rendah membentuk lapisan-lapisan di luarnya, permukiman pertapa tersebut membentuk lingkaran yang konsentris (mandala). Mandala/kedewaguruan ini lazim dibangun di tempat-tempat yang sepi dan jauh dari keramaian, seperti di gunung dan tengah hutan, tempat kaum rsi dan pertapa dapat bermeditasi dan melakukan aktivitas-aktivitas keagamaan secara tenang dan damai.

Pada mandala/kedewaguruan inilah ajaran-ajaran serta pemikiran keagamaan diproduksi dan ditulis oleh para kaum agamawan pujangga/kawi dalam naskah-naskah lontar, seperti tutur. Karena ketinggian ilmu keagamaan di kalangan pemuka-pemuka mandala, tidak jarang raja beserta keluarga serta orang-orang yang ingin memperdalam ilmu agama datang ke tempat tersebut atau bahkan para raja dan tokoh penting pun lazim melakukan pengunduran diri dan menetap pada kompleks tersebut (Santiko, 2005). Naskah Sumanasantaka, sebagai contoh, menyebutkan kisah Pangeran Aja yang singgah pada suatu pertapaan-yang sangat mungkin sekelas mandala-kemudian bertemu dengan kepala pertapaan yang merupakan mantan wiku haji di keraton serta sangat pandai dalam menggubah kakawin. Raja Raghu, ayah Pangeran Aja pun, dikatakan mengundurkan diri ke hutan untuk memperdalam dan melakukan praktikpraktik keagamaan dalam suatu kompleks pertapaan (Zoetmulder, 1983).
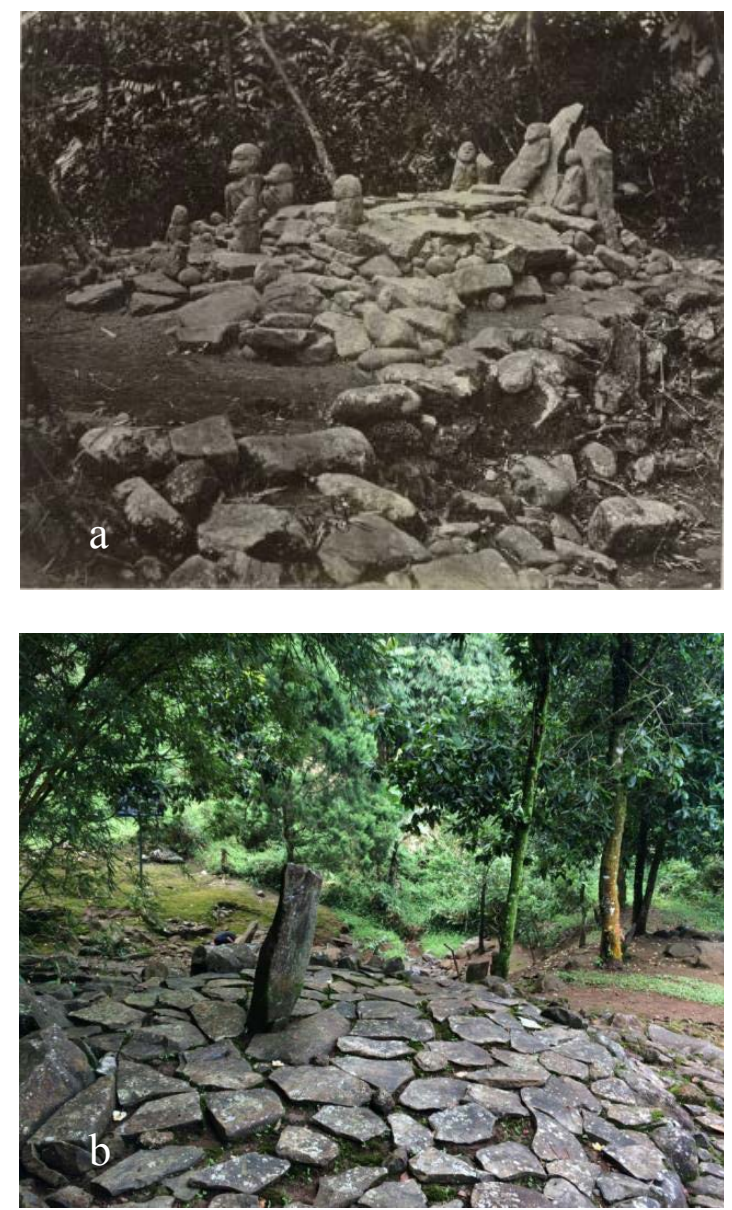

Gambar 3 (a) Foto situs bangunan keagamaan sunda kuno yang berupa punden berundak dengan menhir dan arca yang dipotret akhir 1863/1864 oleh Isidore van Kinsbergen di Megamendung, Bogor, (b) Situs Jamipacing, Cibalay, Kabupaten Bogor; berdasarkan keterangan naskah-naskah kuno, seperti Perjalanan Bujangga Manik, bangunan-bangunan keagamaan seperti inilah yang dipergunakan pada masa Sunda Kuno (Sumber: geheugenvannederland.nl dan Dachlan [2018], dimodifikasi oleh Dani Sunjana)

Kepandaian dan ketinggian ilmu dari para pemuka suatu mandala atau pertapaan sebagai bhujangga pada masa Jawa Kuno terwujud dalamnaskah-naskahkeagamaan, seperti teks tutur dan mantra (Setyawati, 2006). Tidak menutup kemungkinan, pada situs-situs mandala/pertapaan diproduksi pula teks-teks sastra, seperti kakawin dan kidung, misalnya yang dituturkan 
dalam petikan Sumanasantaka di atas atau misalnya yang dikemukakan pada bagian pengantar kakawin Hariwangsa. Dalam bagian pengantar dikatakan bahwa sang pengarang melakukan ritual di puncak gunung untuk memuja Wisnu agar menjadikannya seorang kawi (sastrawan) yang andal dengan menyusun kakawin Hariwangsa (Zoetmulder, 1983). Teksteks lain yang disusun dalam mandala juga meliputi parwa, obat-obatan (Bali: usada), serta primbon seperti pada kasus naskahnaskah Merapi-Merbabu (Setyawati, 2006). Mandala/kedewaguruan dalam beberapa kasus juga memproduksi prasasti-prasasti dalam corak khusus (Susanti, 2018). Dengan sifatnya yang demikianlah, mandala/kedewaguruan atau bahkan pertapaan dikatakan sebagai skriptoria.

Gejala mengenai situs-situs pertapaan atau mandala sebagai skriptoria dari naskah-naskah keagamaan ini ruparupanya juga terjadi pada masa Sunda Kuno. Pada naskah Sanghyang Hayu (Kropak 634 dan 637), Siksaguru, dan Sanghyang Sasana Mahaguru (Kropak 621) disebutkan bahwa naskah tersebut ditulis di Mahapawitra yang dapat dipastikan merupakan kabuyutan di sekitar Gunung Raksa, Panaitan (Gunawan, 2011). Naskah lain, seperti Sewakadarma, juga disusun oleh seorang pertapa perempuan yang bernama Buyut Ni Dawit di pertapaan Ni Teja Puru Bancana Gunung Kumbang. Naskah Amanat Galunggung, meskipun ditemukan dalam koleksi naskah-naskah Ciburuy, harusnya juga berasal dari kabuyutan Galunggung, di Tasikmalaya. Naskah Bujangga Manik pun harusnya ditulis di pertapaan karena sang pengarang jelas-jelas mengatakan dirinya sebagai seorang pertapa, rsi, atau mahapandita. Gejala-gejala adanya situs pertapaan atau mandala sebagai skriptoria ini dikuatkan dengan masih adanya bekas-bekas situs kabuyutan sekaligus skriptorium, seperti kabuyutan Ciburuy di Kabupaten Garut.

Selain kabuyutan dan mandala, jenis bangunan suci selanjutnya adalah kawikuan, pertapaan, dan sakakala. Kawikuan sesungguhnya adalah kompleks bangunan suci yang sama dengan kabuyutan, tetapi penghuninya disebut wiku. Munandar berpendapat bahwa kata wiku sangat mungkin berasal dari kata bhiksu dalam Buddhisme sehingga kawikuan mungkin memiliki nafas Buddha (Munandar, 2017). Pendapat ini agaknya harus dipertimbangkan kembali apabila merujuk pada keterangan dari Prasasti Kebantenan II dan III yang mengatakan bahwa wiku ini tinggal dalam kompleks kabuyutan sehingga wiku sesunggunya setara dengan rama, rsi. Lebih lanjut, Zoetmulder dalam Kamus Jawa KunaIndonesia memberikan pengertian wiku secara umum sebagai orang yang memiliki status religius, orang yang mengabdikan diri pada kehidupan keagamaan, orang suci, dan pertapa atau biarawan (Zoetmulder \& Robson, 2006).

Pertapaan adalah bangunan suci yang digunakan untuk bertapa. Mengenai bentuknya tidak terdapat keterangan yang jelas dalam sumbersumber tertulis Sunda Kuno. Di Jawa dan Bali, bentuk pertapaan ini ada yang memanfaatkan gua alami, ada pula yang memanfaatkan tebing dan dibuat ceruk-ceruk buatan pada tempat- 
tempat yang sepi, seperti gunung, hutan, dan tepi sungai. Pertapaan sangat mungkin digunakan dalam jangka waktu sementara (seasonal), berbeda dengan kabuyutan dan mandala yang memang dilengkapi hunian untuk para rama, $r s i$, atau wiku. Bangunan suci terakhir adalah sakakala. Sakakala merupakan suatu tanda atau tempat peringatan untuk mengenang seseorang atau tanda yang dikeramatkan sebagai simbol konsepsi yang sangat penting dalam bidang keagamaan (Munandar, 2017). Naskah Perjalanan Bujangga Manik menyebutkan dua buah sakakala di Tatar Sunda, yaitu Sakakala Tuhan Cupak di Bukit (Gunung) Caru dan Sakakala Silih Wangi di Jalatunda. Dalam naskah yang sama istilah sakakala juga disebutkan berada di Tanah Jawa, yaitu sasakala untuk mengenang arwah leluhur (bhatara dan bhatari) di Gunung Karungrungan serta Gunung Merapi yang dikatakan Sakakala Darmadewa. Mengenai bentuk sakakala, penjelasan Bujangga Manik pada baris 1285-1290 dapat dijadikan rujukan. Pada bagian tersebut Bujangga Manik menginformasikan bahwa sesampainya di Gunung Sembung dan bertapa, ia melakukan ritual puja nyapu, kemudian mendirikan lingga dan arca sebagai sakakala agar dapat disaksikan oleh generasi-generasi selanjutnya. Dengan demikian, sakakala adalah semacam bangunan peringatan yang ditandai dengan adanya lingga atau arca.

Demikianlah, berdasarkan penelusuran dari sumber-sumber tertulis dan arkeologis tampak bahwa gunung memang telah dijadikan lanskap yang suci untuk membangun situs-situs keagamaan serta skriptoria pada masa Sunda Kuno. Pada perkembangannya, tidak semua bangunan suci keagamaan atau skriptoria Sunda Kuno selalu berada di gunung karena ada yang berada di wilayah daratan rendah. Bangunan-bangunan suci tersebut tetap didirikan dengan cara meninggikan tanah atau menggunakan suatu bukit yang diorientasikan pada gunung/tempat tinggi sebagai simbol yang sakral.

\section{SIMPULAN}

Gunung telah digunakan sebagai simbol yang sakral tempat pwah, hyang, bhatara, dan bhatari dianggap bersemayam pada bagian lereng dan tubuh serta Sang Hyang Manon sebagai wujud jatiniskala berada pada bagian puncaknya. Simbol ini kemudian diwujudkan dengan cara membangun situs-situs keagamaan, berupa kabuyutan, mandala, kawikuan, dewasasana, serta sakakala sebagai upaya untuk mendekatkan diri kepada dewata dan wujud adikodrati sebagai kebenaran tertinggi.

Begitu pula pengetahuanpengetahuan agama, hal tersebut banyak diproduksi dari skriptoria di gunung. Gunung-gunung suci dan sakral ini beberapa di antaranya telah disebutkan dalam sumber-sumber tertulis, ada pula yang tidak disebutkan, tetapi kesakralannya dapat dikonfirmasi melalui data arkeologis. Penelitian di masa yang akan, untuk mengonfirmasi keteranganketerangan sumber tertulis mengenai bangunan suci di Tatar Sunda, akan sangat berguna untuk merekonstruksi serta memperdalam pengetahuan kita mengenai kebudayaan masyarakat Sunda Kuno pada masa silam, Pun, Leuwih luangan, dan kurang wuwuhan. 


\section{DAFTAR PUSTAKA}

Bernbaum, E. (2006). Sacred Mountains: Themes and Teachings. Mountain Research and Development, 26(4), 304-309.

Danasasmita, A.S. (1981). Sanghyang Siksa Kandang Karesian; Naskah Sunda Kuno Tahun 1518 Masehi. Bandung: Proyek Pengembangan Permuseuman Jawa Barat.

Darsa, U. (2010, February 9). Sakola Sunda Kuno. Pikiran Rakyat, p. 14.

Degroot, V. (2009). Candi Space and Landscape: A Study on the Distribution, Orientation and Spatial Organization of Central Javanese Temple Remains. Leiden University.

Ekadjati, E. (2005, June 2). Menguak Konsep Kosmologi Sunda Kuna. Pikiran Rakyat.

Guillaud, D. (2006). Menyelusuri Sungai, Merunut Waktu: Penelitian Arkeologi di Sumatra Selatan. Jakarta: Puslitbang Arkenas, IRD, dan EFEO.

Gunawan, A. (2011). Membaca Teks Sunda Kuna Sanghyang Sasana Maha Guru. Retrieved from www.academia.edu/aditiagunawan

Laneri, N. (2015). Defining The Sacred. London: Oxbow Press.

Moleong, L. (2007). Metode Penelitian Kualitatif. Bandung: Remaja Rosdakarya.

Munandar, A. A. (2016). Arkeologi Pawitra (1st ed.). Jakarta: Wedatama Widya Sastra.

Munandar, A.A. (2017). Siliwangi, Sejarah, dan Budaya Sunda Kuna (1st ed.). Jakarta: Wedatama Widya Sastra.

Ni Ketut Puji Astiti Laksmi, \& Wahyudi, W. R. (2018). Tracing religious life in the ancient Bali period: An Epigraphical Study. In M. Budianta, M. Budiman, A. Kusno, \& M. Moriyama (Eds.), Cultural Dynamics In a Globalized World (I, pp. 553-558). Retrieved from https://scholar.google.co.id/ citations? user $=$ GEnSivwAAAAJ\&hl $=$ en $\# \mathrm{~d}=\mathrm{gs}$ md cita- $\mathrm{d} \& \mathrm{u}=\% 2 \mathrm{~F}$ citations $\% 3 \mathrm{Fview}$ op\%3Dview_citation\%26hl\%3Den\%26user\%3DGEnSivwAAAAJ\%26citation_for_ view\%3DGEnSivwAAAAJ\%3AzYLM7Y9cAGgC\%26tzom\%3D420

Noorduyn, J. (1982). Bujangga Manik'S Journeys Through Java: Topographical Data. 138(1982), 413-442.

Prasetyo, B., \& Yuniawati, D. Y. (2004). Religi pada Masyarakat Prasejarah di Indonesia (1st ed.). Jakarta: Pusat Penelitian dan Pengembangan Arkeologi Nasional.

Santiko, H. (2005). Hari-Hara: Kumpulan Tulisan tentang Agama Veda dan Hindu di Indonesia abad IV-XVI M (1st ed.). Depok: Universitas Indonesia.

Saringedyanti, E. (1996). Penempatan Situs Upacara Masa Hindu-Buda: Kajian Lingkungan Fisik Kabuyutan di Jawa Barat. Universitas Indonesia.

Septiani, S. (2010). Aktivitas Keagamaan Masyarakat Kerajaan Sunda Abad ke-14 hingga Awal Abad ke-16 Masehi berdasarkan Data Tertulis dan Tinggalan Arkeologis: Suatu Penelitian Awal. Universitas Indonesia.

Setiawan, H. (2019). Bujangga Manik dan Studi Sunda. Tidak diterbitkan.

Setyawati, K. (2006). Mantra pada Koleksi Naskah Merapi-Merbabu. Humaniora, 18(1), 6371. 
Soejono, R. (2008). Sistem-Sistem Penguburan pada Akhir Masa Prasejarah di Bali. Jakarta: Pusat Penelitian dan Pengembangan Arkeologi Nasional.

Sulistyarto, P. H. (2003). Pola Sebaran Situs Megalitik di Gunung Slamet. Yogyakarta.

Susanti, N. (2018). 'Variety of Distinct Style Scripts in Inscriptions Found in Mandalas of the Late Majapahit Era: An Overview of the Paleography to Mark Religious Dynamics. In M. Budianta, M. Budiman, A. Kusno, \& M. Moriyama (Eds.), Cultural Dynamics in a Globalized World (1st ed., pp. 585-592). Retrieved from https://scholar.google.co.id/ citations?user=GEnSivwAAAAJ\&hl=en\#d=gs_md_cita-d\&u=\%2Fcitations\%3Fview_ op\%3Dview_citation\%26hl\%3Den\%26user\%3DGEnSivwAAAAJ\%26citation_for_ view\%3DGEnSivwAAAAJ\%3AzYLM7Y9cAGgC\%26tzom\%3D420

Tim Penulis Sejarah Nasional Indonesia. (2009). Sejarah Nasional Indonesia II: Zaman Kuno (6th ed.; M. D. Poesponegoro \& N. Notosusanto, Eds.). Jakarta: Balai Pustaka.

Widjajadi, A. W. (2018). Arca-arca yang Hilang di Gunung Wayang. Retrieved March 21, 2019, from Komunitas Aleut website: https://komunitasaleut.com/2018/02/13/arca-arca-yanghilang-di-gunung-wayang/

Williams, G. M. (2003). Handbook of Hindu Mythology (1st ed.). California: ABC-CLIO.

Yondri, L. (2018). Jejak Aktivitas Penguburan Masyarakat Megalitik di Kaki Gunung Ciremai, Jawa Barat. Retrieved from www.academia.edu/lutfiyondri

Zoetmulder, P. J. (1983). Kalangwan: Sastra Jawa Kuno Selayang Pandang (2nd ed.). Jakarta: Djambatan.

Zoetmulder, P. J., \& Robson, S. (2006). Kamus Jawa Kuno-Indonesia. Jakarta: Kepustakaan Populer Gramedia. 
PURBAWIDYA ם Vol. 8, No. 2, November 2019 